\title{
Chapter 12 \\ The CSR Performance and Earning Management Practice on the Market Value of Conventional Banks in Indonesia
}

\author{
Saarce Elsye Hatane \\ (iD) https://orcid.org/0000-0002-3797-1623 \\ Petra Christian University, Indonesia \\ Amadea Nathania Pranoto \\ Petra Christian University, Indonesia \\ Josua Tarigan \\ Petra Christian University, Indonesia \\ Josephine Alexandra Susilo \\ Petra Christian University, Indonesia \\ Ang Jonathan Christianto \\ Petra Christian University, Indonesia
}

\begin{abstract}
This study examined the effect of the components of corporate social responsibility (CSR) and earnings management on market value, measured using Tobin's Q. CSR is measured by using KLD Index, while earnings management used discretionary loan loss provision. The GMM-SYS (generalized method of moment system) dynamic panel data method is employed to examine the research framework on conventional banks listed in Indonesia Stock Exchange. Among six components in CSR disclosures, only corporate governance, environmental and product disclosures are favorable for bank's market value.
\end{abstract}


Furthermore, earnings management had a positive impact on market value. Empirical result indicated that CSR functions as a part of bank strategic moves in order to survive the highly dynamical business environment. Since CSR inflicts additional costs for the company, they must perform CSR efficiently while maintaining a strong relationship with shareholders. This study contributes to CSR and financial management literature by finding the nature of CSR effects as future strategic investment.

\section{INTRODUCTION}

The banking sector in Indonesia (Hatane et al., 2019) is experiencing a slowdown from decreasing credit quality within the last five years. In 2016, President Joko Widodo also enacted a regulation for banks to reduce their loan rates (Nugroho, 2016). While the government tried to lower the interest rate, banks were facing a series of bad credits. The rise of non-performing loans caused by bad credits has presented a challenge for banks in restoring public trust and building clear, transparent business numbers. On the other hand, banks must also comply with the regulation and reduce lending rates. As a result, banks are indirectly required to implement social, ethical, and responsible approach in their business environment to regain public trust. Corporate social responsibility (CSR) has become a global trend for companies in gaining public trust as well as achieving sustainability. Companies seek to show their concern for the community while promoting organizational participation and position in the market. By applying CSR, firms can benefit from better positioning, even if this necessitates them in spending extra costs. However, having a good image and good firm quality on the market can encourage employees to work productively and achieve higher financial performance (Devie et al. 2018).

CSR in banking is related to its environment, community, and products (Aracil, 2019). The main product of a bank is any facility or service related to cash management, therefore, the important elements for the welfare of banks are finance, customers, and society. A socially responsible bank is accountable to take on responsibility for the impact of its activities on society. Concern for environmental sustainability by banks gave rise to the concept of green banking. The need to adopt green banking practices is considered very important because of its environmental, corporate, and social benefits for the economy (Ibe-Enwo et al. 2019). Secondly, to gain customer and society trust, banks need integrity and transparency to operate (Banking for society, n.d.). Banks are means used by the public to invest their funds. Therefore, banks are very important to have a high level of transparency.

When a company is being transparent by divulging what struggles are being faced, it is doing voluntary disclosure. Yim et al. (2019) contended that by voluntarily disclosing information, the company doing CSR is signaling the public on its quality. To increase customer confidence, companies must reduce information asymmetry. Earnings management is often related to information asymmetry because the concept of earnings management is to manipulate earnings. In the process, profit manipulation can be done to make the company look profitable in that period. However, a socially-responsible corporate has a low incentive to manage earnings (Hong \& Andersen, 2011); in other words, a company with poor CSR activities has a higher rate of earnings management. It is hoped that by running CSR well enough, 
while also having a low level of earnings management, banks have a better reputation and firm market value will increase.

Based on previous studies, it is generally agreed that CSR activities increase market value (Aras et al., 2018; Cho et al., 2019). Feng et al. (2017) said that different type of CSR has a different effect on the market value. However, on the contrary, Omar \& Zallom (2016) found that some CSR components can lower market value. Moreover, Chtourou \& Triki (2017) argued instead that as long as it does not harm the company, CSR can be implemented for long-term business sustainability purposes. Therefore, studies on the impact of CSR and financial performance have yielded inconclusive results. Additionally, many prior studies discuss the impact of CSR on financial performance on non-financial companies (Oh and Park, 2015; Sial et al. 2018; Gangi et al, 2018; Ho et al. 2019). There are limited studies found on the impact of CSR and earnings management on the market value of the banking sector. Whereas, the banking sector plays an important role in maintaining a country's economic stability and wealth (Hatane et al. 2019). Moreover, most studies focus on the CSR of Islamic banks, however not on conventional banks. To fill in the literature gap, this research provides valuable insight into CSR and its relation with the market value of banks listed in the Indonesia Stock Exchange (Bursa Efek Indonesia, BEI). This research tries to give insights into how CSR can be a strategic approach to achieve sustainability. Its influence on the environment, society, and communities has to, therefore, be measured with different perspectives. In order to achieve the objective, this study uses the KLD Index as a multidimensional approach in measuring CSR performances. Therefore, making the objective of this study is to test the impact of CSR and earnings management on the market value of conventional banks in Indonesia. Section 2 states the background theory of CSR and earnings management, followed by prior researches on CSR and financial performance relationships. Then, in Section 3, the research methodology is explained. Finally, Section 4 discusses the results and solutions; Section 5 provides conclusions and limitations.

\section{BACKGROUND}

Corporate social responsibility is associated with voluntary acts by a company in social or environmental forms to propose society's welfare (Omar \& Zallom, 2016). Various practices are taken by a company ranging from donating money, to concern for the environment, and to promote the firm's transparency. Preserving the environment, the concept of green banking comes into action. Green banking promotes environmentally friendly practices and reduces the carbon footprint of banking activities. It aims to improve operations and technology together by making environmentally friendly client habits in banking activities, thus benefiting the community as well. CSR practices aren't limited to donations and environmentally recycle, but also on the willingness to reveal factual issues that happen to the company. On top of that, the responsibility practices done by a company can become their strategy to enhance the corporate's reputation (Devie et al. 2018). Moreover, on gaining public trust, banks shall promote transparency by signaling the public. In the long term, CSR is a strategic approach in navigating dynamic business activities and reaching a sustainable environment (Carini et al., 2017).

Companies adopting social responsibility practices reduce information asymmetry (Su et al., 2014) and prevent adverse selection (Yu et al., 2017). This is often linked with signaling theory. Signaling theory explains firms' efforts to signal the public regarding their motivation and goodwill (Yu et al., 2017). Information asymmetry arises from inside information that is not being published by one party. It occurs when a party (in a situation) has more information than the other party, or in other words, one of the par- 
ties benefits from the information in its possession. Signaling theory discusses information asymmetry between two parties where the source of asymmetric information is mainly related to information about quality or intention (Su et al., 2014). Quality concerns about how one party reacts by showing its true attitudes toward receiving premium benefits from the other party. The intention relates to how to diminish the possibility of a moral hazard resulting from the behavior of the parties exchanging information.

Yim et al., (2019) argues that companies engaged in CSR provide a signal to society about their high quality. It is most likely that the company doing CSR performances are perceived to be more honorable by showing altruistic values toward society. In that case, they are less likely to possess a moral hazard. Yu et al., (2017) states that based on signaling theory, companies can provide intangible information through voluntary disclosure to strengthen their competitive advantage and capability in the market. As a company discloses its CSR performances voluntarily, a company not only shows that it is complying with the laws and regulations but also to declare its legitimacy. Deegan (2002) mentioned legitimacy theory is developing voluntary, social, and environmental disclosures to fulfill their social contract that enables the recognition of the organization's objectives. It is a system that backs up the business organization during turbulence. Adhering to the legal obligation is a prerequisite to meet the responsibility (Mullerat \& Brennan, 2005). When the social expectation rises and the organization's activities do not meet moral values, an entity should defend itself through legitimate economic and social actions. Companies that are practicing CSR are considered to be more respectable since they demonstrate altruistic values in addition to their legitimate obligations (Gras-Gil et al., 2016). Through the integration of CSR performance, banks indirectly have an impact on society that is being sustainable. Encouraging social and environmental responsibility toward sustainability can increase firm market value (Aras et al., 2018; Cho et al., 2019). By implementing CSR, firms can benefit from better market positioning. Thus the research hypothesis for this paper is formed:

Hypothesis One: Corporate social responsibility positively affects market value.

Based on agency theory, conflict of interest may push managers to manage earnings. In the banking industry, the manager's motivation to manage profits is to minimize profit volatility from time to time (Othman \& Mersni, 2014). Loan Loss Provision (LLP) is used by banks as a proxy to manage earnings. The purpose of this is to set aside a certain amount to be used as a bad debt reserve. Manipulation is a part of information asymmetry. Normally, socially responsible firms have low incentives to manage earnings. In other words, firms with poor CSR activities have a higher activity level of earnings management (Gras-Gil et al. 2016). A high activity level of earnings management can mislead financial statement users. The low quality of information generated from the adverse selection can affect a company's market value investor (Ujah et al., 2017). A company with a high level of integrity and credibility will acquire the public's trust (Mukherjee \& Nuñez, 2019), and so raises its market value. Market value embodies investors' opinions on a company, which is reflected in the equity market value. Market value can also depict future profits through investors' evaluation. Banks with integrity and high credibility can increase public trust (Mukherjee and Nuñez, 2019). Thus, the second hypothesis is formed:

Hypothesis Two: Earnings management negatively affects market value.

To capture the multi-dimension of CSR, this paper uses an extensively used approach, the KLD Index formulated by Kinder, Lydenberg, and Domini to measure CSR (Devie et al., 2018; Ho et al., 2019; 
Chantziaras et al., 2020). The index is divided into two categories: strengths and concerns. Strengths refer to the additional ability of a firm; concerns are matters concerning the inability to achieve the goal of strengths. While under the two categories, seven components comprise of Community, Corporate governance, Diversity, Employee relations, Environment, Human rights, and Products (Sun \& Rakhman, 2013).

\section{RESEARCH METHODOLOGY}

\section{Sampling and Data Collection}

The study used secondary data taken from annual reports, financial reports, Bloomberg databases, and other trustworthy sources. The population in this study is 42 conventional banks listed in Indonesia Stock Exchange (BEI). The banks must have continuously published annual reports in 2012-2018. They must also have the necessary information as needed for variable measurement. The sample is thus 31 companies in the banking sector, with a seven-year observation period from 2012-2018.

The purpose of the research is to investigate whether CSR and earnings management affects market value in a positive, negative, or neutral way. To resolve the endogeneity problem, this study uses the GMM-SYS (generalized method of moment system) dynamic panel data method (Lin et al., 2018) since GMM has the largest correction effect on coefficients. The problem of endogeneity stems from the fact that causality can run in both the direction of independent to dependent variables and vice versa. A reciprocal relationship can happen between both variables. The GMM-SYS method was developed to overcome the correlation problem between the dependent variable and any existing error in the GMM estimator (Oh \& Park, 2015).

Dynamic panel data has three steps in testing the validity and reliability of a model:

\section{Arellano-Bond test}

The Arellano-Bond test is done to diagnose any serial correlation. The null hypothesis of the test is that there exists autocorrelation on error. The null hypothesis of the Arellano-Bond test for serial correlation is:

- H0: there is no autocorrelation

- $\mathrm{H} 0$ is rejected if $\mathrm{p}$-value $<1 \%, 5 \%, 10 \%$

Arellano-Bond test has two orders, AR 1 and AR 2 as seen in Table 1. The test is consistent if H0 is rejected (on three significant levels of 1, 5, and 10\%) on AR 1, but is not rejected on AR 2 (Lin et al., 2018). As seen in Table $1, \mathrm{H} 0$ is rejected as the p-value is 0.0581 which is significant on a $10 \%$ level. For AR2, it is supposed to be above a significant level, and the value agrees with the theory, 0.3691 .

2. Sargan test 
On the GMM model, it is important to know the validity of the instrumental variable which amount exceeds the estimated parameter (over-identification). The Sargan test tries for the validity of overidentification restrictions, on where p-values are reported. The null hypothesis of the Sargan test is:

- H0: the limit of over-identification is valid

- $\quad \mathrm{H} 0$ is rejected if p-value $<1 \%, 5 \%, 10 \%$

For this test, it is expected for the p-value to be above the significant levels of 1, 5, and $10 \%$; in other words, the null hypothesis is not rejected. The Sargan test on over-identifying restrictions presents a higher p-value, implying that there is no over-identification problem, and so it can be said that the model is valid. As shown in Table 1, the Sargan test resulted in 0.2596 which aligned with the theory implying there is no problem exists concerning over-identification.

\section{Wald test}

This test is used in simultaneously testing the significance of parameters that are used for the model between dependent and independent variables, distributed in asymptotic Chi-square, with null hypothesis stating that there is no relationship in the estimated model, and HO is rejected if the p-value is < $\alpha$. The Wald test is used to determine if the variables employed in the tested model are simultaneously significant. Therefore, the null hypothesis of the Wald test is:

- Ho: there are no relations between variables in the model.

- $\mathrm{H} 0$ is rejected if p-value $<1 \%, 5 \%, 10 \%$

The Wald test is expected to reject the null hypothesis, with rejection occurring if $\mathrm{p}$-value $<1 \%, 5 \%$, $10 \%$, and so the rejection of the null hypothesis in the Wald test becomes the objective of the estimator (Habimana, 2016). As seen in Table 1, the result of the Wald test is 0.0000 , which rejected the null hypothesis with a p-value of $<1 \%$.

Table 1. Validity and reliability test

\begin{tabular}{|l|l|l|}
\hline Test for AR(1) errors & $\mathrm{z}=-1.89504$ & {$[0.0581]$} \\
\hline Test for AR(2) errors & $\mathrm{z}=-0.898199$ & {$[0.3691]$} \\
\hline Sargan over-identification test & Chi-square(19) $=22.5101$ & {$[0.2596]$} \\
\hline Wald (joint) test & Chi-square(12) $=22196.8$ & {$[0.0000]$} \\
\hline Sum squared residual & 2.592302 & \\
\hline S.E. of regression & 0.122411 & \\
\hline
\end{tabular}

Table 1 shows that the model is valid and reliable as it has fulfilled the three requirements of validity and reliability test. 


\section{Measurements}

\section{Measurement of Corporate Social Responsibility}

Following previous studies (Matuszak et al., 2019; Chantziaras et al., 2020), the measurement used for CSR is KLD Index. KLD Index was developed to support social studies and comprehensively measure a company's social activities. KLD Index was chosen to measure CSR since this index is multidimensional, thus capable of picturing the company from a variety of dimensions. The KLD Index has been used as a CSR measurement tool in various studies. There are seven empirical indicators: community, corporate governance, diversity, employee relations, environment, human rights, and product. These components are further separated into two categories, which are strength (the company's strength or advantages) and concern (any problem inside or related to the company that needs special attention). Every bank that has fulfilled the strength or concern are numbered 1, and 0 when it doesn't. To make the data more reliable, each data are calculated as a ratio (value divided by the average). The KLD Index used in this study is a holistic approach from both the good and the bad sides of the company to measure social performance. The following is a brief explanation of the CSR components:

\section{Community}

Discusses the treatment of a company on its surrounding community. Community activities can be through donations, financial aid, or social support towards the community in the vicinity of or outside the company's environment.

\section{Corporate governance}

This refers to a set of policies or regulations that affect the process of management and control in a company or corporation.

\section{Diversity}

Relates to the diversity of board members and employees. A company is said to have more diversity when it has a Chief Executive Officer that is a woman or a member of a minority group; when it has made important progress in promoting women and/or minority groups; when it has a diverse board of directors; when it provides benefit, care, and job for disabled people; and other forms of diversity.

4. Employee relations

Refers to the relations among the company employees.

\section{Environment}

This refers to how the company acts regarding its surrounding environment.

6. Human rights 
Relates to the rights and obligations of the company's consumers and employees, as dictated by the law.

7. Product

The most important category; this part explores the quality and detail of a product that is developed by a company. In this study, a bank's financial service is the product.

\section{Measurement of Earnings Management}

Earnings management in the banking sector is achieved through the reduction of discretionary accruals from the total accrual. For this sector, earnings management is often reflected by Loan Loss Provision (LLP) (Othman \& Mersni, 2014; Ujah et al., 2017). Banks use LLP to manage their earnings. The total accrual is represented by LLP. Table 2 displays the operational definition to measures the bank's earnings management. The empirical indicator is LLP obtained from:

LLP $=$ Non-discretionary LLP (NDLLP) + Discretionary LLP (DLLP)

Thus, DLLP is obtained by subtracting NDLLP from LLP. Based on previous research (Othman \& Mersni, 2014), the estimation method utilized to find DLLP is:

DLLPit $=$ LLPit $-[\beta 0+\beta 1 N P L i t-1+\beta 2 \Delta N P L i t+\beta 3 \Delta$ TLit $]$.

Where:

Table 2. The operational definition of earnings management

\begin{tabular}{|l|l|}
\hline \multicolumn{1}{|c|}{ Component of Earnings Management } & \multicolumn{1}{c|}{ Definition } \\
\hline Loan loss provision (LLPit) & The total of loan loss provision on bank $i$ in year $t$, divided by an initial credit balance \\
\hline $\begin{array}{l}\text { Non-performing loans } \\
\text { (NPLit }-1)\end{array}$ & $\begin{array}{l}\text { The opening balance of non-performing loans on bank } i \text { in year } t \text {, divided by an initial } \\
\text { credit balance }\end{array}$ \\
\hline$\Delta$ PLit & $\begin{array}{l}\text { The difference of non-performing loans on bank } i \text { in year } t \text {, divided by an initial credit } \\
\text { balance }\end{array}$ \\
\hline$\Delta \mathrm{L}$ & The difference of total credit on bank $i$ in year $t$, divided by an initial credit balance \\
\hline
\end{tabular}

\section{Measurement of Market Value}

The empirical indicator employed to measure market value is Tobin's Q. Tobin's Q does not only provide a snapshot of a company's value but also investors' view on the company which is reflected from the equity value. Tobin's $\mathrm{Q}$ is calculated from the market value of equity (market capitalization) plus total liabilities and divided by total assets (Nawaz, 2017). Table 3 presents the operational definition of each variable that is examined in the research model. 
The CSR Performance and Earning Management Practice on the Market Value of Conventional Banks

To test the hypotheses and see the effect of the CSR components and earnings management have on the market value of conventional banks in Indonesia, the following regression model is employed:

$$
\begin{aligned}
& \text { TOBQit }=\beta 0+\beta 1 \text { COMit }+\beta 2 \text { CGit }+\beta 3 \text { DIVit }+\beta 4 \text { EMPit } \\
& +\beta 5 \text { ENVit }+\beta 6 \text { HRit }+\beta 7 \text { PRODit }+\beta 8 D L L P i t+\beta 9 \text { SIZEit }+\beta 10 C A R i t+\beta 11 L D i t+\varepsilon
\end{aligned}
$$

\section{Measurement of Control Variables}

\section{Firm Size (SIZE)}

Based on market capitalization, the size of the company can be reflected from the total assets owned by the company. Measurement of company size is done to distinguish quantitatively between large companies and small companies. The natural logarithm of total assets is known as the proxy for firm size. Thus, it is evident that firm size reflects the financial performance of a company (Nawaz, 2017).

\section{Capital adequacy ratio (CAR)}

Capital Adequacy Ratio (CAR) is the ratio of a capital structure owned by the company. CAR is obtained from the average total equity divided by the average total assets. In developing countries, a stable capital structure is very important especially for financial institutions because it can help in dealing with a crisis (Menicucci and Paolucci 2016). Thus, CAR can reflect how sturdy the company's capital structure is. The higher the value of CAR, the better the capital structure of the company.

\section{Loan to deposit (LD)}

Loan to deposit is used to represent external financing (Othman and Mersni, 2014). To be able to obtain external financing, banks report low LLP to reduce perceived risk and to increase reported income, so that it provides appealing numbers to the eyes of investors. A high LD ratio shows that total loans are greater than deposits. Therefore, banks need to withdraw more deposits from customers to increase liquidity. For that matter, bank managers have an incentive to report low LLP. Thus, the level of earnings management through DLLP is negatively related to the demand for external financing. The variables and their definitions are as follows.

\section{RESEARCH RESULTS AND ANALYSIS}

The analysis of the descriptive statistics of each variable is explained in this part. Table 4 briefly illustrates the data used in this study, by using several parameters such as mean, median, standard deviation (S.D.), minimum, and maximum values.

As shown in Table 4, each CSR component in the data has a uniformly distributed value as seen from the standard deviation (S.D.), which is close to 0 (unbiased), except for CAR and LD. This is shown in the standard deviation (S.D.) column that seven components have a value of less than 1 (the community 
Table 3. Variables definition

\begin{tabular}{|l|l|}
\hline \multicolumn{1}{|c|}{ Variable } & \\
\hline & COM = Community \\
& CG = Corporate governance \\
& DIV = Diversity \\
& EMP = Employee relations \\
& ENV = Environment \\
CSR = Human rights & PROD = Product \\
& For each component, the difference from the total score of strength and the total score of \\
& concern is divided by the number of categories. The components and categories of details \\
& are included in the Appendix. \\
\hline Tobin's Q (TOBQ) & Market capitalization plus total liabilities divided by total assets \\
\hline \multirow{2}{*}{ Discretionary loan loss provision (DLLP) } & The measurement of earnings management (total accruals minus non-discretionary \\
& accruals) \\
\hline Firm Size (SIZE) & Natural logarithm of total assets \\
\hline Capital adequacy ratio (CAR) & The average of total equity divided by the average of total assets \\
\hline Loan-to-deposit ratio (LD) & Total loan divided by total deposit \\
\hline
\end{tabular}

has a value of 0.176 , corporate governance 0.173 , and so on). However, based on the mean values shown, all banks on average have a high CAR value of 13.929. As regulated by the Financial Services Authority Regulations (Otoritas Jasa Keuangan, OJK) Number 03/2016, the capital structure standard for the banking sector ranges from $8 \%$ to $14 \%$, and this percentage varies depending on the bank's ranking. The higher the ranking, the higher is the capital structure, which is demanded by Financial Services Authority Regulations, to secure company assets. The mean of CAR is 13.929, thus on average, all banks in the sample have a good quality of CAR without considering the ranking. Thus, high data distribution (S.D.) on CAR which is 5.041 has no significant effect.

Table 4. Descriptive statistics analysis

\begin{tabular}{|l|c|c|c|c|c|}
\hline \multicolumn{1}{|c|}{ Variable } & Mean & Median & S.D. & Minimum & Maximum \\
\hline Community (COM) & 0.753 & 0.714 & 0.176 & 0.000 & 1.000 \\
\hline Corporate Governance (CG) & 0.872 & 1.000 & 0.173 & 0.000 & 1.000 \\
\hline Diversity (DIV) & 0.290 & 0.375 & 0.181 & -0.125 & 0.500 \\
\hline Employee (EMP) & 0.610 & 0.571 & 0.224 & 0.000 & 1.000 \\
\hline Environment (ENV) & 0.681 & 0.833 & 0.308 & 0.000 & 1.000 \\
\hline Human Rights (HR) & 0.521 & 0.500 & 0.214 & 0.000 & 1.000 \\
\hline Product (PROD) & 0.733 & 0.750 & 0.190 & 0.000 & 1.000 \\
\hline DLLP & -0.001 & -0.002 & 0.013 & -0.030 & 0.077 \\
\hline Firm Size & 30.975 & 30.786 & 1.938 & 26.961 & 34.799 \\
\hline CAR & 13.929 & 13.279 & 5.041 & 0.137 & 35.514 \\
\hline LD & 86.688 & 87.255 & 14.821 & 43.460 & 146.376 \\
\hline Tobin's Q & 1.072 & 1.025 & 0.152 & 0.529 & 1.593 \\
\hline
\end{tabular}


In contrast, LD exhibits a very large deviation, meaning the LD from the Indonesian conventional banks' sample is highly variable as we can see from the S.D. which is 14.821. LD illustrates external funding (Othman \& Mersni, 2014), considering each bank has a different funding structure depending on its size. This result can be explained as a consequence of rising bad credit up through 2016. There exists a highly difficult condition for banks, causing widespread data distribution (Sari, 2016). An explanation is then derived that banks that suffer from unstable capital structure need additional capital. They must use external funding in order to maintain their liquidity. Diversity has a minus minimum score of -0.125 . This means that the concern issues exceed the strengths. High concern for diversity arises because of the non-representation issue, that is, the lack of women on the board of directors when the research is conducted.

Table 5. Hypotheses testing (CSR components)

\begin{tabular}{|c|c|c|c|}
\hline \multirow{2}{*}{ Variable } & \multicolumn{2}{|c|}{ Conventional Banks (DP) } & \multirow{2}{*}{ Significance Result } \\
\hline & Coefficient & P-value & \\
\hline Tobin's Q (t-1) & 0.893408 & $<0.0001^{* * *}$ & \\
\hline Const & -0.155595 & $0.0157^{* * *}$ & \\
\hline Community & -0.0384439 & $0.0663^{*}$ & Sig - \\
\hline Corporate Governance & 0.0915947 & $<0.0001^{* * *}$ & $\mathrm{Sig}+$ \\
\hline Diversity & -0.0375903 & $0.0105^{* *}$ & Sig - \\
\hline Employee relations & -0.0234789 & $0.0069^{* * *}$ & Sig - \\
\hline Environment & 0.0208300 & $0.0443 * *$ & $\operatorname{Sig}+$ \\
\hline Human rights & 0.0120698 & 0.4266 & In Sig \\
\hline Product & 0.0486374 & $<0.0001 * * *$ & Sig + \\
\hline DLLP & 1.28258 & $<0.0001 * * *$ & $\mathrm{Sig}+$ \\
\hline Size & 0.00224933 & 0.1599 & In Sig \\
\hline CAR & 0.00220793 & $0.0004 * * *$ & Sig + \\
\hline LD & 0.00101749 & $<0.0001^{* * *}$ & $\operatorname{Sig}+$ \\
\hline
\end{tabular}

Notes: $* \mathrm{p}<0.10$ (weakly significant); $* * \mathrm{p}<0.05$ (significant); ${ }^{* * *} \mathrm{p}<0.01$ (highly significant).

Table 5 exhibits the test result on the impact of each CSR and earnings management, along with the control variables (Size, CAR, LD), on market value.

The research agrees with Feng et al. (2017) that every component has a different effect on market value. As seen in Table 5 of the significant results column, four out of seven CSR components positively affect market value, three of them affect significantly, and one is insignificant, which is human rights. The three components which affect negatively are community, diversity, and employee relations. This is shown by the minus coefficients of $-0.0384439,-0.0375903$, and -0.0234789 consecutively. Results are contrary to previous studies which found that all CSR activity has a positive significant relationship with market value (Aras et al., 2018; Cho et al., 2019). Conforming to Omar \& Zallom (2016), the community negatively impacts market value.

Tobin's Q contains the equity market value components which involve investors' reasoning in determining firm value. Yet, DLLP which indicates the existence of earnings management instead raises market 
value. This is consistent with the output of the negative significant impact some CSR components have on Tobin's Q. During the administration of President Joko Widodo, the government imposed a reduction in loan interest rates (Nugroho, 2016). Bad credit became the main problem of Indonesian banks, which could logically explain this situation. The community has a negative value (coefficient of -0.0384439 ) since there are more concerns than strengths due to negative economic impact (an aspect of Community), namely bad credit, during the observation period. The diversity value is also negative because of the lack of women on the board of directors' composition, causing higher concern value compared to strength. Banks can improve their diversity as it is an internal factor. Tang (2019) wrote that from 2016 through 2018, bank employees suffered from lay-offs due to digitalization and automation processes, these results in negative impact by employee relations. What happened to these banks is an unavoidable outside factor. Banks are pressured to reduce lending rates, but at the same time, they are facing bad credits. As a result, banks are not liquid and face a crisis in obtaining working capital. Working capital is used to fund the banks' daily operational activities and is obtained from current assets minus current liabilities. According to Megeid (2017), if a bank faces a liquidity crisis, it is necessary to borrow additional funds in order to fulfill liquidity requirements and raise loan loss provision. This is supported by the data in Table 5, which shows that Loan-to-Deposit (LD) correlates positively with Tobin's Q (a positive coefficient of 0.00101749), meaning market value (Tobin's Q) grows when Loan-to-Deposit increases. To resolve the lack of working capital, banks chose to apply for long-term external funding to fund the organization, instead of short-term funding. This leads to an increase in total loans. Supposed that in the observation period the economic condition is normal, both community and employee relations might generate positive results, and therefore six CSR components (community, corporate governance, diversity, employee relations, environment, and products) would positively impact market value.

Corporate governance, environment, and product have a significant positive impact on market value as seen by the positive coefficients of $0.0915947,0.0208300$, and 0.0486374 consecutively. The human rights component has a positive impact on market value but not significantly. Therefore, management must pay attention to developing CSR activities related to corporate governance, environment, and products.

Looking at a different perspective, these banks displayed transparency by doing voluntary disclosure on factual ongoing information, in this case, bad credit. Banks demonstrated high integrity by being transparent (Mukherjee \& Nuñez, 2019) since they chose to do voluntary disclosure. This act reduces information asymmetry and thus acknowledges the signaling theory. By this theory, a company gives out a positive signal to the public that there are no hidden motives to harm customers, by this means society; instead, they were facing a financial crisis. The result shown in Table 5 may be caused by the possibility that investors choose to see the result of the company's financial performance. Investors value financial statements more compared to the CSR section (ACCA, 2008). They contend that being transparent and accountable towards the society and environment does not benefit company profitability, so they choose to see only the final result of financial performance. Therefore, this affects the equity market value, which resulted in a significant negative impact of CSR on Tobin's Q.

In this study, it is hypothesized that earnings management negatively affects market value because of the adverse selection of information by management. However, in this result, the second hypothesis is rejected since earnings management affects market value positively (as seen in the coefficient of DLLP is 1.28258 with positive significance result). This result isn't consistent with the previous study that said loan loss provisions are negatively related to banking performance (Wu et al., 2016). It is found that by reserving provisions, banks have a better result. During the observation period, banks are facing a financial crisis, which was bad credit. Due to the economic impact, banks need liquid assets. To 
The CSR Performance and Earning Management Practice on the Market Value of Conventional Banks

cope with the situation, they set aside LLP to be used as a bad debt reserve. This can logically explains the situation why earnings management resulted in a positive impact on banking performance, which is market value in this study.

\section{Control Variable Analysis}

The research model also considers three control variables: Firm Size (SIZE), Capital Adequacy Ratio (CAR), and Loan-to-Deposit (LD). The finding of the control variables analysis is summarized in Table 5. Only CAR and LD are consistent in playing their roles as control variables, shown by significant results of $0.0004 * * *$ and $<0.0001 * * *$ consecutively with a p-value of less than $1 \%$ (highly significant). Contrary to previous studies, SIZE does not significantly influence financial performance (Nawaz, 2017). A large bank does not necessarily have a better performance than a smaller bank. Therefore, firm size is not a significant factor. On the other hand, CAR and LD both significantly affect market value. CAR captures a market-based approach and consists of total assets and total equity. A strong and significant link is found between CAR and Tobin's Q. Tobin's Q includes equity market value, which explains why CAR is significant to Tobin's Q. A significant positive relationship is also found on LD to Tobin's Q. In other words, external funding as reflected by LD enhances market value. As the bank increases external funding (total loans), its equity level also rises, and so does its loan-to-deposit rate.

\section{SOLUTIONS AND RECOMMENDATIONS}

Managers of conventional banks should make a budget plan in advance before doing CSR, to make sure that the benefits from CSR outweigh its costs. For the bad credit, banks must prepare a portfolio on liquidity risk. In case it occurs in the future, banks are ready to face without practicing excess earnings management by reserving a high value of DLLP. Banks should also increase the diversity in the board of directors, for example by giving the female employee a chance for duty, enforcing equal rights. Since corporate governance, environment, and product are positively impacting market value, managers are recommended to develop CSR activities relating to them. The environment is one of the most prominent CSR components in this study. This component assesses how banks contribute positively or at least not to pollute the environment. Banks do not directly damage the environment. The concept of green banking is developing along with the attention of the banking industry in protecting the environment. Green banking is translated as an effort by banks to prioritize the fulfillment of sustainability in lending or operational activities. The use of energy, water, and other natural resources in banking activities is not as severe as the use by other sectors, such as mining and processing industries. To enhance developing CSR activities related to environment and product, banks can adopt the concept of green banking. Green banking practices can be in the form of paperless banking, internet banking, paperless automated teller machines (ATMs), renewable energy and energy efficiency can be implemented by adopting energysaving technologies, installing solar panels to create alternative energy, recycling and recyclable products (Kumar \& Prakash, 2018). However, banking cannot necessarily be released from the problem of increasing environmental degradation. By providing loans or financing to its customers, banks can be a trigger for activities that have an impact on the environment.

Regulators are expected to make appropriate considerations related to the interests of stakeholders. In this study, it is found that banks tend to focus on environmental greening activities and donations 
to the surrounding community. They overlook the innovation of product components, specifically not emphasizing disclosure related to green banking. Thus, it is recommended for banks to focus on disclosure of product innovation with the concept of green banking. Since business moves dynamically, any CSR measurement used must be adapted for its era. It is recommended that future studies pay attention to the existing popular movements, as there is a chance for CSR measurement methods to evolve in the future. Hence, future research should use a measurement that has been adjusted with the existing period.

\section{CONCLUSION}

The purpose of this study is to recognize the impact of CSR and earnings management on the market value of conventional banks. The study uses data taken from annual reports and Bloomberg database between 2012 and 2018. The first hypothesis examines the relationship between CSR, as an independent variable, and market value. CSR consists of seven components which comprise of community, corporate governance, diversity, employee relations, environment, human rights, and product. The result shows that each CSR component has a differing influence on market value. The second hypothesis tests the effect of earnings management on market value. The second hypothesis is not accepted as there is a significant positive effect of DLLP on market value. When a bank experiences bad credits, it needs working capital, so it sets to borrow from external parties increasing loan loss provision. This explains why earnings management positively impacts market value. However, if the excess practice of earnings management is done, it results in information asymmetry and could harm the company's reputation.

CSR should have been able to help banks increase market value. However, during the observation period, a series of bad credits and mass lay-offs caused by digitalization and automation happened, therefore resulted in differing influences on market value. Nevertheless, there are logical causes that explain why community, diversity, and employee relations have a negative effect. As long as it does not harm the organization, CSR is a good approach for the company in achieving business sustainability (Devie et al. 2018). Suppose the economic condition is fairly normal during the period, it leads to a better result. Investors can support CSR activities carried out by banks to achieve business sustainability goals that can also minimize business risks in the future.

\section{LIMITATIONS}

The research has several limitations; one being the number of the bank sample size used is very limited, considering not all conventional banks in Indonesia made their data available. Future studies should research all conventional banks in Indonesia. Additionally, this study only investigated market value, and only used a single measurement for market value using Tobin's Q. Measurement of a company's financial performance can be done from more than one side, which is not only market value, it can also be viewed from the profitability or return on investment. Therefore, the next studies should also employ more thorough data with a better approach and holistic measurement. 
The CSR Performance and Earning Management Practice on the Market Value of Conventional Banks

\section{REFERENCES}

ACCA. (n.d.). Social and environmental narrative reporting: analysts' perceptions. https://www.accaglobal.com/gb/en/technical-activities/technical-resources-search/2008/november/perceptions-narrativereporting.html

Aracil, E. (2019). Corporate social responsibility of Islamic and conventional banks. International Journal of Emerging Markets, 14(4), 582-600. doi:10.1108/IJOEM-12-2017-0533

Aras, G., Tezcan, N., \& Furtuna, O. K. (2018). The value relevance of the banking sector multidimensional corporate sustainability performance. Corporate Social Responsibility and Environmental Management, 25(6), 1062-1073. doi:10.1002/csr.1520

Banking for Society. (n.d.). What do we mean by corporate social responsibility and socially responsible banking? Author.

Carini, C., Comincioli, N., Poddi, L., \& Vergalli, S. (2017). Measure the performance with the market value added: Evidence from CSR companies. Sustainability, 9(12), 2171.

Chantziaras, A., Dedoulis, E., Grougiou, V., \& Leventis, S. (2020). The impact of religiosity and corruption on CSR reporting: The case of U.S. banks. Journal of Business Research, 109, 362-374. doi:10.1016/j.jbusres.2019.12.025

Cho, S., Chung, C., \& Young, J. (2019). Study on the relationship between CSR and financial performance. Sustainability, 11(2), 343. doi:10.3390u11020343

Chtourou, H., \& Triki, M. (2017). Commitment in corporate social responsibility and financial performance: A study in the Tunisian context. Social Responsibility Journal, 13(2), 370-389. doi:10.1108/ SRJ-05-2016-0079

Deegan, C. (2002). Introduction: The legitimising effect of social and environmental disclosures - a theoretical foundation. Accounting, Auditing \& Accountability Journal, 15(3), 282-311. doi:10.1108/09513570210435852

Devie, D., Liman, L. P., Tarigan, J., \& Jie, F. (2018). Corporate social responsibility, financial performance and risk in Indonesian natural resources industry. Social Responsibility Journal, 16(1), 73-90. doi:10.1108/SRJ-06-2018-0155

Feng, M., Wang, X., \& Kreuze, J. G. (2017). Corporate social responsibility and firm financial performance. American Journal of Business, 32(3/4), 106-133. doi:10.1108/AJB-05-2016-0015

Gangi, F., Mustilli, M., \& Varrone, N. (2019). The impact of corporate social responsibility (CSR) knowledge on corporate financial performance: Evidence from the European banking industry. Journal of Knowledge Management, 23(1), 110-134. doi:10.1108/JKM-04-2018-0267

Gras-Gil, E., Manzano, M. P., \& Fernández, J. H. (2016). Investigating the relationship between corporate social responsibility and earnings management: Evidence from Spain. BRQ Business Research Quarterly, 19(4), 289-299. doi:10.1016/j.brq.2016.02.002 
Habimana, O. (2016). Do flexible exchange rates facilitate external adjustment? A dynamic approach with time-varying and asymmetric volatility. International Economics and Economic Policy, 14(4), 625-642. doi:10.100710368-016-0341-7

Hatane, S. E., Octavia, F., \& Florentina, J. (2019). The comparison of earnings management practices in Indonesia's Islamic banks and conventional banks. Advances in Economics. Business and Management Research, 69, 127-131.

Ho, A. Y.-F., Liang, H.-Y., \& Tumurbaatar, T. (2019). The impact of corporate social responsibility on financial performance: Evidence from commercial banks in Mongolia. Advances in Pacific Basin Business, Economics and Finance, 109-153.

Hong, Y., \& Andersen, M. L. (2011). The relationship between corporate social responsibility and earnings management: An exploratory study. Journal of Business Ethics, 104(4), 461-471. doi:10.100710551011-0921-y

Ibe-Enwo, G., Igbudu, N., Garanti, Z., \& Popoola, T. (2019). Assessing the relevance of green banking practice on bank loyalty: The mediating effect of green image and bank trust. Sustainability, 11(17), 4651. doi:10.3390u11174651

Kumar, K., \& Prakash, A. (2018). Developing a framework for assessing sustainable banking performance of the Indian banking sector. Social Responsibility Journal, 15(5), 689-709. doi:10.1108/SRJ07-2018-0162

Lin, W., Ho, J., \& Sambasivan, M. (2018). Impact of corporate political activity on the relationship between corporate social responsibility and financial performance: A dynamic panel data approach. Sustainability, 11(1), 60. doi:10.3390u11010060

Matuszak, Ł., Różańska, E., \& Macuda, M. (2019). The impact of corporate governance characteristics on banks' corporate social responsibility disclosure. Journal of Accounting in Emerging Economies, 9(1), 75-102. doi:10.1108/JAEE-04-2017-0040

Megeid, N. S. A. (2017). Liquidity risk management: Conventional versus Islamic banking system in Egypt. Journal of Islamic Accounting and Business Research, 8(1), 100-128. doi:10.1108/JIABR-05-2014-0018

Menicucci, E., \& Paolucci, G. (2016). The determinants of bank profitability: Empirical evidence from European banking sector. Journal of Financial Reporting and Accounting, 14(1), 86-115. doi:10.1108/ JFRA-05-2015-0060

Mukherjee, A., \& Nuñez, R. (2019). Doing well by doing good: Can voluntary CSR reporting enhance financial performance? Journal of Indian Business Research, 11(2), 100-119. doi:10.1108/JIBR-072018-0199

Mullerat, R., \& Brennan, D. (2005). Corporate social responsibility: The corporate governance of the 21st century. International Bar Association.

Nawaz, T. (2017). Momentum investment strategies, corporate governance and firm performance: An analysis of Islamic banks. Corporate Governance: The International Journal of Business in Society, 17(2), 192-211. doi:10.1108/CG-03-2016-0052 
Nugroho, B. P. (2016). Jokowi: I will find a way to reduce loan interest rate. https://finance.detik.com/ moneter/d-3119293/jokowi-saya-akan-cari-jalan-agar-bunga-kredit-turun

Oh, W., \& Park, S. (2015). The relationship between corporate social responsibility and corporate financial performance in Korea. Emerging Markets Finance \& Trade, 51(3), 85-94. doi:10.1080/15404 96X.2015.1039903

Omar, B. F., \& Zallom, N. O. (2016). Corporate social responsibility and market value: Evidence from Jordan. Journal of Financial Reporting and Accounting, 14(1), 2-29. doi:10.1108/JFRA-11-2014-0084

Othman, H. B., \& Mersni, H. (2014). The use of discretionary loan loss provisions by Islamic banks and conventional banks in the Middle East region. Studies in Economics and Finance, 31(1), 106-128. doi:10.1108/SEF-02-2013-0017

Sari, E. V. (2016). September 2016 non-performing loans is higher than last year. https://www.cnnindonesia.com/ekonomi/20161107114502-78-170819/kredit-macet-september-2016-lebih-tinggi-dibandingtahun-lalu

Sial, M., Zheng, C., Khuong, N., Khan, T., \& Usman, M. (2018). Does firm performance influence corporate social responsibility reporting of Chinese listed companies? Sustainability, 10(7), 2217. doi:10.3390u10072217

Su, W., Peng, M. W., Tan, W., \& Cheung, Y.-L. (2014). The signaling effect of corporate social responsibility in emerging economies. Journal of Business Ethics, 134(3), 479-491. doi:10.100710551-014-2404-4

Sun, L., \& Rakhman, F. (2013). CFO financial expertise and corporate social responsibility. International Journal of Law and Management, 55(3), 161-172. doi:10.1108/17542431311327619

Tang, W. (2019). Banks lay off employees due to automation, digitalization. https://www.thejakartapost. com/news/2019/03/31/banks-lay-off-employees-due-to-automation-digitalization.html

Ujah, N. U., Brusa, J., \& Okafor, C. E. (2017). The influence of earnings management and bank structure on bank performance. Managerial Finance, 43(7), 761-773. doi:10.1108/MF-12-2015-0329

Wu, Y. C., Wei Kiong Ting, I., Lu, W. M., Nourani, M., \& Kweh, Q. L. (2016). The impact of earnings management on the performance of ASEAN banks. Economic Modelling, 53, 156-165. doi:10.1016/j. econmod.2015.11.023

Yim, S., Bae, Y. H., Lim, H., \& Kwon, J. (2019). The role of marketing capability in linking CSR to corporate financial performance. European Journal of Marketing, 53(7), 1333-1354. doi:10.1108/ EJM-08-2017-0526

Yu, H.-C., Kuo, L., \& Kao, M.-F. (2017). The relationship between CSR disclosure and competitive advantage. Sustainability Accounting. Management and Policy Journal, 8(5), 547-570. 
The CSR Performance and Earning Management Practice on the Market Value of Conventional Banks

\section{APPENDIX}

Table 6.

\begin{tabular}{|c|c|c|}
\hline Categories & Strengths & Concerns \\
\hline \multirow[t]{8}{*}{ Community } & Generous giving & Investment controversies \\
\hline & Innovative giving & Negative economic impact \\
\hline & Housing support & Indigenous people relations \\
\hline & Education support & Tax disputes \\
\hline & Peoples relations & Other Concerns \\
\hline & Non-US giving & \\
\hline & Voluntary programs & \\
\hline & Other strength & \\
\hline \multirow[t]{6}{*}{ Corporate governance } & Limited compensation & High Compensation \\
\hline & Ownership strength & Ownership concern \\
\hline & Transparency strength & Transparency concern \\
\hline & Accountability strength & Accountability concern \\
\hline & Public policy strength & Public policy concern \\
\hline & Other strength & Other concerns \\
\hline \multirow[t]{8}{*}{ Diversity } & CEO & Controversies \\
\hline & Promotion & Non-representation \\
\hline & Board of directors & Other concerns \\
\hline & Work-life benefits & \\
\hline & Women and minority & \\
\hline & Employment of the disabled & \\
\hline & Gay and lesbian policies & \\
\hline & Other strength & \\
\hline \multirow[t]{7}{*}{ Employee relations } & Union relations & Union relations \\
\hline & No-layoff policy & Health and safety concern \\
\hline & Cash profit sharing & Workforce reductions \\
\hline & Employee involvement & Retirement benefits concern \\
\hline & Retirement benefits & Other concern \\
\hline & Health and safety & \\
\hline & Other strengths & \\
\hline \multirow[t]{7}{*}{ Environment } & Beneficial products & Hazardous waste \\
\hline & Pollution prevention & Regulatory problems \\
\hline & Recycling & Ozone depleting chemicals \\
\hline & Clean energy & Subtantial emissions \\
\hline & PPE & Agriculture chemicals \\
\hline & Other strengths & Climate change \\
\hline & & Other concern \\
\hline \multirow[t]{4}{*}{ Human rights } & Positive record in Indonesia & Labor right concern \\
\hline & Indigenous people relations & Indigenous people relations concern \\
\hline & Labor rights strength & Other concerns \\
\hline & Other strengths & \\
\hline \multirow[t]{4}{*}{ Products } & Quality & Product safety concern \\
\hline & R\&D, innovation & Marketing contracting concern \\
\hline & Benefits to economically disadvantage & Antitrust \\
\hline & Other strength & Other concern \\
\hline
\end{tabular}

